\title{
Protocol of Mensuration to Avaliation of Indicators of Somatic Development of Wistar Rats
}

\author{
Protocolo de Medidas para Evaluación de Indicadores de Desarrollo Somático en Ratas Wistar \\ "Hilton Justino da Silva; "Sônia Maria Oliveira Cavalcanti Marinho; *Ana Elisa Toscano Meneses da Silva; \\ "Claudio Gonçalves de Albuquerque; *"Silvia Regina Arruda de Moraes \& *Raul Manhães de Castro
}

SilVA, H. J.; MARINHO, S. M. O.; SIlVA, A. E. T. M.; AlbUQUERQUE, C. G.; MORAES, S. R. A. \& MANHÃES DE CASTRO, R. Protocol of meensuration to avaliation of indicators of somatic development of Wistar rats. Int. J. Morphol., 23(3):227230, 2005.

SUMMARY: Evaluations of weight and cephalic perimeter are very used to study the growth and development in human beings. Similar measures, called murinometrics, have been an efficient resource to study the effects of nutritional and pharmacologic manipulations on the somatic development in rat. The aim of this study is to describe a method of evaluation which offers a higher accuracy in the collect of data in the study of somatic development in Wistar rat. Measurements were realized in latero-lateral axis of skull; Antero-posterior axis of skull; Longitudinal axis; Length of tail in 60 wistar rat during breastfeeding period. The most suitable method of measurement respects predetermined anatomic points, the use of the suitable scapus of pachymeter as well as its accuracy.

KEY WORDS: Somatic development; Morphology; Wistar rat.

\section{INTRODUCTION}

The events of growth and development occur according to a well determined temporal sequence (Morgane et al., 1993; Turlejski, 1996).

Evaluations of weight, height and cephalic perimeter relating to age are amply used in human beings to avaliate the growth and the development as well as the nutritional state (OMS, 1995).

Similar measures are also used to avaliate the somatic development in rat, subjected to the effects of nutritional and pharmacologic manipulations and can be defined as murinometrics (Deiró, 1998; Barros, 1999).

However, it was observed the absence of studies which describe a standard method of evaluation to determine the somatic development in rat.

The aim of this study is to describe a more accurate method of evaluation to study the somatic development in Wistar rat.

\section{MATERIAL AND METHOD}

60 male albino Wistar rat from the colony of Departamento de Nutrição da Universidade Federal de Pernambuco were used. The animals were kept in an environment at a temperature of $23 \pm 1^{\circ} \mathrm{C}$, in a light cycle (6am to $6 \mathrm{pm}$ ) and darkness cycle (6pm to 6am) constant. The animals had free access to filtered water and standard ration (LABINA - Purina do Brasil, with $23 \%$ of protein).

To estabilish the method, the animals were subjected to daily murinometric evaluations during 21 days (breastfeeding period), from $12 \mathrm{am}$ to $2 \mathrm{pm}$. The following measures were considered: latero-lateral axis of skull (LLAS); Antero-posterior axis of skull (APAS); Longitudinal Axis (LA); Length of tail (LT).

To obtain these measures it was used a stainless steel pachymeter, Starret with an accuracy of $0,02 \mathrm{~mm}$.

It was also considered the evaluation of corporal weight $(\mathrm{CW})$, using a digital eletronic balance Marte, model S-4000, with capacity of $4 \mathrm{~kg}$ and sensibility of $0,1 \mathrm{~g}$. The

\footnotetext{
* Departamento de Nutrição, Universidade Federal de Pernambuco Recife. Brasil.

** Departamento de Anatomia, Universidade Federal de Pernambuco, Recife, Brasil. Sponsorship: CNPQ - Edital Universal - Process n ${ }^{\circ}$ 473535/2003-3.
} 
method was described in stages some of them were photographed using a digital camera (Sony FD Mavica Quick Acess FD Drive) for a better visualization of the results.

The procedures used in this study are according to the rules suggested by the Colégio de Experimentação Animal and the international rules established by the National Institute of Health Guide for Care and Use of Laboratory Animals which were adopted by the Comissão de Ética em Experimentação Animal da Universidade Federal de Pernambuco - CEEA-UFPE to avaliate and judgment process $N^{\circ} 005603 / 2004-51$

\section{RESULTS}

After the evaluation of the 60 albino Wistar rat, the appropriate approach has the following stages:

\section{Latero-lateral axis of skull (LLAS).}

1.1 Hold the animal using one hand, with its head between the index finger and the thumb.

1.2 Consider the line perpendicular to the longitudinal axis of skull, from the point of insertion more mesial and superior of the ears in the skull of the animal. (Fig. 1a)

1.3 Obtain the measure considering the two points of insertion in each ear using the scapus of the pachymeter to measure the external ends. (Fig. 1b)

2. Antero-posterior axis of skull (APAS).

2.1 Hold the animal using one hand, with its head between the index finger and the thumb.

2.2 Locate in the skull of the animal the region of external occipital crest (Greene, 1955). Mark this point with a pen (Fig. 2a.).

2.2 Obtain this measure taking as reference a media line from the end of the muzzle to the marked point of crest, using the scapus of the pachymeter to measure the external ends.(Fig. 2b)

\section{Length of tail (LT).}

3.1 Hold the animal supine and consider the region of the anus as anatomic point (Fig 3a)

3.2. Obtain this measure from the anus to the stretched tail, using the scapus of the pachymeter to measure the depth (Fig 3b)

4. Longitudinal axis (LA).

4.1. Hold the animal with the ring finger, the middle finger and the index finger of the researcher.

4.2. Consider the points of the region of the anus and the muzzle of the animal. Hold the animal in ventral decubitus on a flat and smooth surface.

4.3. Support the scapus of the pachymeter that measures depth parallel to the body of the animal. (Figura 4).

\section{Corporal weight $(\mathrm{CW})$.}

Add to this evaluation the measure of corporal weight of the animal to establish its evolution.

\section{DISCUSSION}

It is important to emphasize that the choice of the scapus of the pachymeter must be done according to the evaluated structure. Silva \& Cunha (2003) emphasize that the scapus of the pachymeter to measure external structures is the most used, although in a not appropriate way by the most of researchers'.

The scapi used in the elaboration of the method of this study are according to Mandarim de Lacerda (1995). The scapus for external structures used to measure the axes LLAS and APAS is suitable for structures with two bases of support.

The scapus for depth used to measure the length of LT and LA is suitable for structures with only the external base of support.

The choice of the scapus of the pachymeter for depth in the measure of the length of the tail and the longitudinal axis is due to the impossibility of take these measures using the scapus for external structures since the anus does not show an anatomic point of support for this procedure.

Some scientific works which use the same experimental model of this study have shown an absence of data that establish a higher accuracy of the measurements. Silva \& Cunha (2003), suggest the use of a pachymeter with an accuracy of 0,02 in the scientific works, since the use of this resource provides more reliable data, as well as more accurate data of the somatic development.

Deiró and Barros for the measure of APAS considered the media line from the end of the muzzle to the point of intersection with other imaginary perpendicular line; for the measure of LLAS, the imaginary line perpendicular to the longitudinal axis of skull, dividing the pinnas in the middle; for the measure of LT the posterior end of the body of the animal at the edge of a table flat and smooth and the tail kept stretched on the table, making a mark coincident with the end of the tail; for the measure of EL compressing the regions dorso-anterior, dorso-posterior of the body and the tail of the animal to a flat surface, marked the table with points coincident with the muzzle and the base of the tail of the animal.

The suggested method consider the anatomic points as a base for the measurements: the insertion point more mesial and superior of the ears in the skull of the animal (LLAS); the region of external occipital crest (APAS); the region of the anus and the end of the tail (LT); the region 


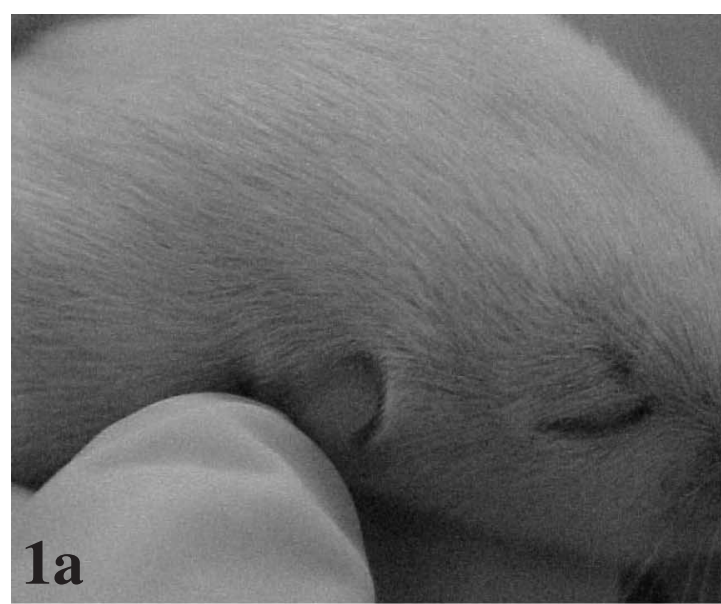

Fig. 1a. Point of insertion more mesial and superior of the ears in the skull.

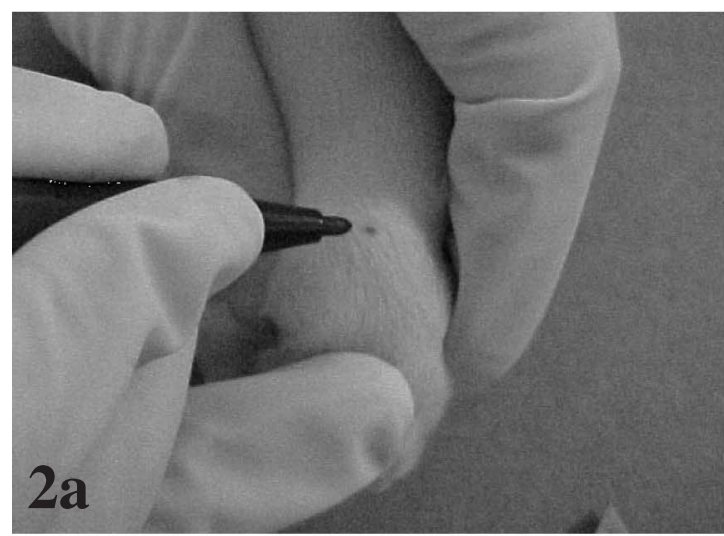

Fig. 2a. Marking of point with red pen.

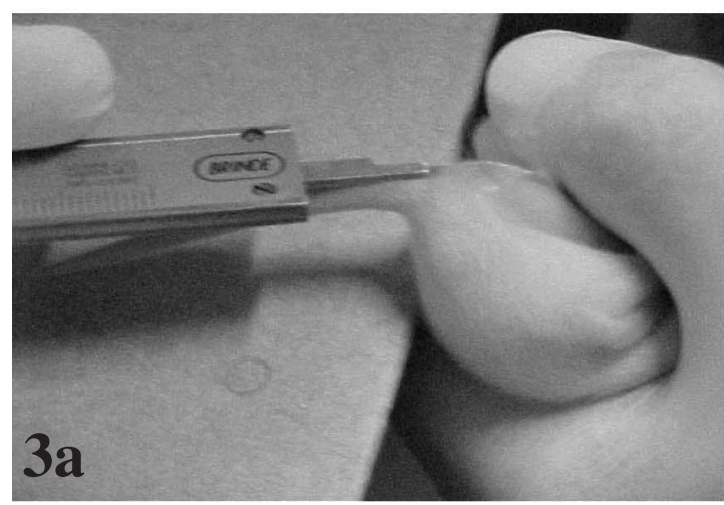

Fig. 3a. Location of the anus.

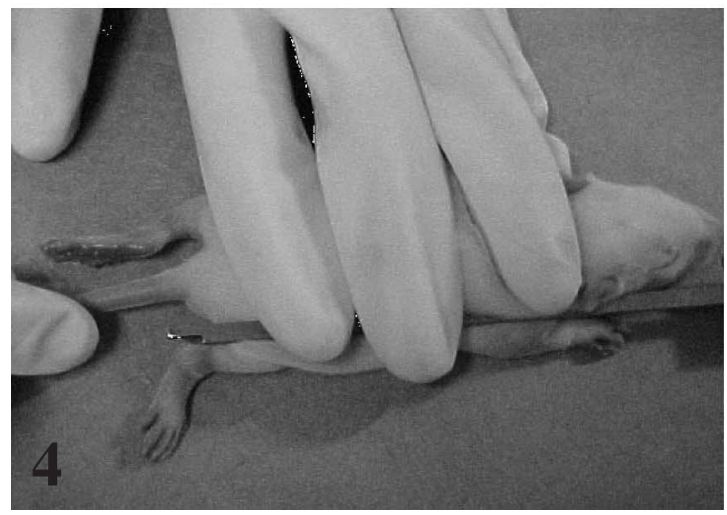

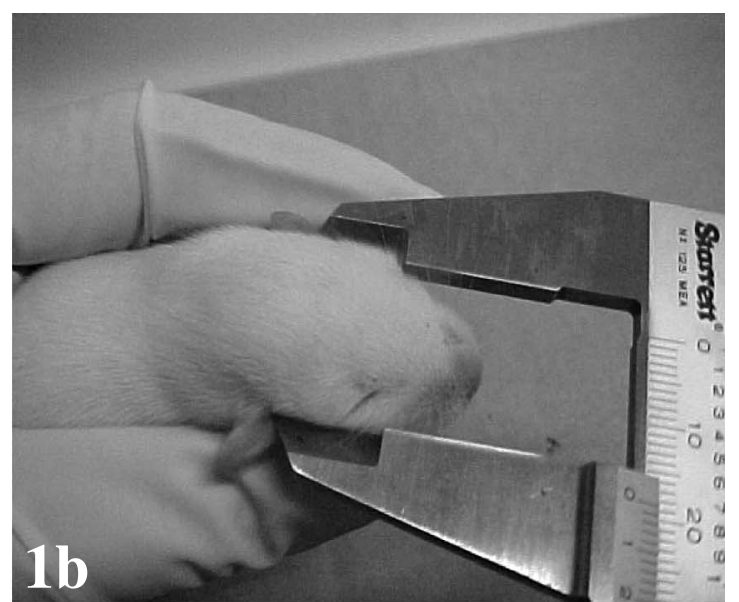

Fig. 1b. Distance between the two anatomic points of each ear (measure of latero-lateral axis of skull).

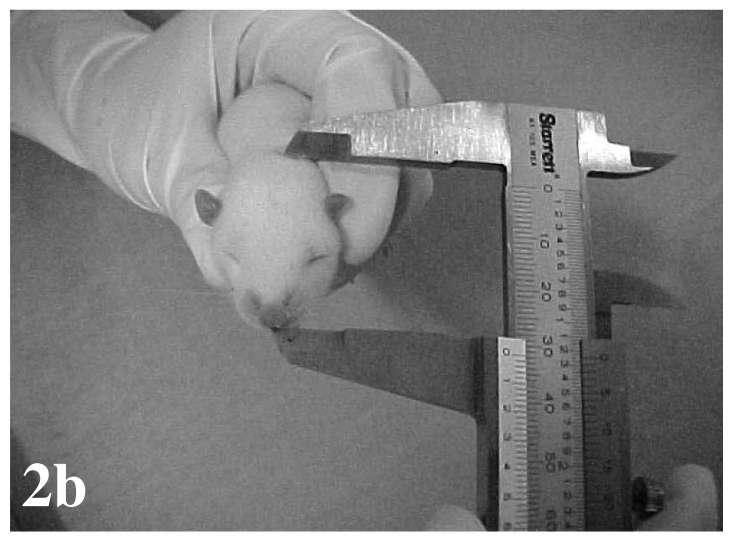

Fig. 2b. Obtaining the measure taking as reference a media line from the end of the muzzle to the marked point of crest.

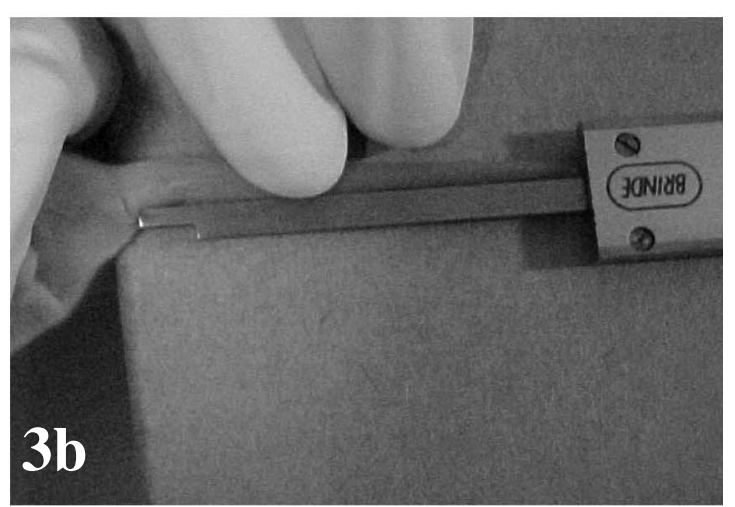

Fig. $3 b$. Measure of the tail from the point of the anus to the end of the stretched tail.

Fig. 4. Obtaining of longitudinal axis (LA) considering the points of the region of the anus and the muzzle of the animal. 
of the anus and the region of the muzzle of the animal (LA). The definition of these points establishes more reliable daily measurements of the indicators of the somatic development.

Other studies evaluated the somatic development in Wistar rat in particular the ones of our laboratory
LAFINT (Deiró; Barros; Magalhães, 2000; Freitas-Silva, 2002).

The suggestion of evaluation of this study represents the first step for a normative of procedures, which establish the necessary accuracy in studies of morphologic development.

SILVA, H. J.; MARINHO, S. M. O.; SILVA, A. E. T. M.; ALBUQUERQUE, C. G.; MORAES, S. R. A. \& MANHÃES DE CASTRO, R.. Protocolo de medidas para evaluación de indicadores de desarrollo somático en ratas Wistar. Int. J. Morphol., 23(3):227230, 2005.

RESUMEN: Evaluaciones de peso y perímetro cefálico son muy utilizadas para el estudio del crecimiento y desarrollo en humanos. Medidas semejantes, denominadas murinométricas, han sido un recurso eficiente para el estudio de los efectos de manipulaciones nutricionales y farmacológicos sobre el desarrollo somático en ratas. El objetivo de este trabajo fue describir un método de evaluación que ofrece mayor exactitud en la recolección de los datos, en el estudio del desarrollo somático en ratas Wistar. Fueron realizadas medidas en el eje látero-lateral del cráneo (ELLC); eje ántero-posterior del cráneo (EAPC); eje longitudinal (EL) y largo de la cola (LC), en 60 ratas Wistar, durante el periodo de amamantación. Se observó, como método más adecuado de medición, el que se relaciona con puntos anatómicos predefinidos, uso del asta adecuada del instrumento de medida (paquímetro), así como la precisión de su exactitud.

PALABRAS CLAVE: Desarrollo somático; Morfología; Ratas Wistar.

\section{REFERENCES}

Barros, K. M. F. T. Efeitos da desnutrição neonatal elou do tratamento com agonista 5-htla sobre o desenvolvimento sensório-motor e atividade exploratória em ratos. Dissertação (Mestrado). - Departamento de Nutrição Universidade Federal de Pernambuco, Recife, 1999.

Deiró, T. C. B. J. Desenvolvimento somático e sensóriomotor e padrão adulto do consumo alimentar, em ratos: efeitos do tratamento neonatal com inibidor de recaptação da serotonina durante o período de crescimento rápido do encéfalo. Dissertação (Mestrado). - Departamento de Nutrição - Universidade Federal de Pernambuco, Recife, 1998.

Freitas- Silva, S. R. Efeitos precoces e tardios da desnutrição e de manipulações neonatais do sistema de recaptação da serotonina sobre parâmetros comportamentais $e$ imunológicos. Dissertação (Mestrado) - Departamento de Nutrição - Universidade Federal de Pernambuco, Recife, 2002.

Greene, E. C. Anatomy of the rat. New York, Hafner Publishing Company, 1955. 365pp.

Magalhães, P. Efeito do tratamento neonatal com inibidor seletivo de recaptura da serotonina sobre o desenvolvimento anatômico crânio-encefálico. Dissertação (Mestrado) - Departamento de Nutrição Universidade Federal de Pernambuco, Recife, 2000.
Mandarim-de-Lacerda, C.A. Métodos quantitativos em morfologia. São Paulo, Eduerj, 1995. 131pp.

Morgane, P. J.; Austin-Lafrance, R. J.; Bronzino, J.; Tonkiss, J.; Diaz-Cintra, S.; Cintra, L.; Kemper, T. \& Galler, J. R. Prenatal malnutrition and development of the brain. Neuroscience and Biobehavioral Reviews, 17: 91-128, 1993.

OMS Physical Status: The Use and Interpretation of Anthropometry. (Technical Report Series, 854), Genebra, OMS, 1995.

Silva, H. J. \& Cunha, D. A. Considerações sobre o uso do paquímero em motricidade oral. Rev. Fono. Brasil, 2:5964, 2003.

Turlejski, K. Evolutionary ancient roles of serotonin: longlasting regulation of activity and development. Acta Neurobiol. Exp., 56:619-36, 1996.

Correspondence to:

Prof. Hilton Justino da Silva

Rua da Saudade, 21 QD/31

Paratibe-Paulista-Pernambuco

CEP 53413-070

BRASIL

Email: filtonfono@aol.com

Received: 10-03-2005

Accepted: 20-06-2005 